\title{
A coumarin-based fluorescence resonance energy transfer probe targeting matrix metalloproteinase-2 for the detection of cervical cancer
}

\author{
GUANGJIE HE ${ }^{1 *}$, LU YANG $^{2 *}$, XINLAI QIAN ${ }^{2}$, JING LI $^{1}$, ZHIQING YUAN ${ }^{2}$ and CHANGZHENG LI ${ }^{2}$ \\ ${ }^{1}$ Department of Forensic Medicine, ${ }^{2}$ School of Basic Medical Science, \\ Xinxiang Medical University, Xinxiang, Henan 453003, P.R. China
}

Received June 1, 2016; Accepted April 27, 2017

DOI: $10.3892 /$ ijmm.2017.2974

\begin{abstract}
Cervical cancer is one of the most common gynecological malignancies worldwide. At present, the methods used for cervical cancer screening have many disadvantages. Matrix metalloproteinase-2 (MMP-2) is low or absent in normal cervical epithelial cells while overexpressed in cervical intraepithelial neoplasia and cervical cancer, which provides the possibility for the detection of cervical cancer based on MMP-2. The development of a strategy with high sensitivity and specificity for cervical cancer detection would be expected to improve the cure rate. Connecting a fluorophore [7-(diethylamino)-2-oxo-2H-chromene-3-succinimidyl ester] with a quencher \{4-[4-(dimethylamino)phenylazo] benzoic acid $N$-succinimidyl ester $\}$ via an MMP-2 substrate peptide GPLGVRGKGG, a new coumarin-based fluorescence resonance energy transfer probe targeting MMP-2 was prepared to examine cervical cancer by cell imaging. The cervical cancer cell lines showed green fluorescence with intensities in the order of $\mathrm{CaSki}>\mathrm{SiHa}>\mathrm{C} 33 \mathrm{~A}>\mathrm{HeLa}$, which indicated that the cervical cancer cell lines possessed significantly differential expression levels of MMP-2. Quantitative (real-time) PCR, RT-PCR, and western blot experiments were consistent with such results. The fluorescence detection limit of the probe for MMP-2 was estimated to be $0.05 \mathrm{ng} / \mathrm{ml}$. Therefore, this MMP-2 probe potentially provides a sensitive and specific
\end{abstract}

Correspondence to: Dr Guangjie He, Department of Forensic Medicine, Xinxiang Medical University, 601 Jinsui Road, Xinxiang, Henan 453003, P.R. China

E-mail: guangjiehe@163.com

Professor Zhiqing Yuan, School of Basic Medical Science, Xinxiang Medical University, 601 Jinsui Road, Xinxiang, Henan 453003, P.R. China

E-mail: yuanzhiqing@xxmu.edu.cn

*Co-first authors

Keywords: cervical cancer, matrix metalloproteinase-2, fluorescence resonance energy transfer, fluorescent probe, coumarin visual method for cervical cancer screening, diagnosis and prognostic judgment.

\section{Introduction}

Approximately 300,000 women die of cervical cancer every year worldwide. Cervical cancer is one of the most common gynecological malignancies and the third-leading cause of cancer-related deaths among females in middle-income countries. In China, its incidence ranks second after breast cancer among gynecological malignancies $(1,2)$. In recent years, the average age of patients has gradually become younger. Research data have shown that cervical cancer occurs most frequently among females aged 50 years or older. The disease develops from cervical intraepithelial neoplasia to cervical cancer via an evolutionary process that takes $\sim 10-20$ years. This pre-malignant period is an important stage for the prevention of cervical cancer as, in theory, the development of a malignant tumor could be blocked using targeted therapies. It is therefore necessary to perform the screening, diagnosis and treatment of cervical cancer patients at the earliest stage possible.

At present, the methods mainly used for the screening of cervical cancer include colposcopy examination, cytology and human papilloma virus detection $(3,4)$. Nevertheless, these methods have certain drawbacks, such as the possibility of false-positives and false-negatives, as well as high cost. Although cervical biopsy is a significant method for the diagnosis of cervical cancer, it causes traumatic injury. Therefore, the development of a fluorescence probe with high sensitivity and specificity is highly desirable and significant for the early diagnosis and prognosis of cancer (5-8).

Extracellular matrix-degrading enzymes mainly fit into 3 categories: serine proteases, cysteine proteinases, and matrix metalloproteinases (MMPs). Among these enzymes, MMPs account for $>70 \%$ of the total activity of extracellular matrixdegrading enzymes (9). MMPs are specific endopeptidases that can degrade a variety of extracellular matrix proteins and remodel damaged tissue. In addition, MMPs play a key role in mediating tumor invasion and metastasis by compromising the integrity of barriers composed of extracellular matrix at the interfaces between different tissues. The activation of MMPs 
is considered to be the rate-limiting step in the degradation of the extracellular matrix $(10,11)$. The gene encoding MMP-2 is located on human chromosome 16q21 and consists of 13 exons and 12 introns, and the molecular weight of the MMP-2 protein is $72 \mathrm{kDa}(12,13)$. MMP-2 is also known as type IV collagenase or gelatinase and functions as a zinc-dependent protease. The primary substrate of MMP-2 is type IV collagen, but it also has activity towards collagen types V, VII, IX and X, as well as fibronectin and elastin. In various tumors, MMP-2 is often overexpressed in an inactive zymogen form that can be converted into active MMP-2 through lysis by membrane type matrix metalloproteinase-1 (MT1-MMP). MMP-2 and MT1-MMP are considered to be closely involved in tumor invasion, metastasis and angiogenesis (14). Tissue invasion and metastasis are the leading causes of death among cancer patients (15). Therefore, building a molecular imaging probe for the evaluation of MMP-2 and MT1-MMP proteolytic activity would help to predict tumor malignancy.

MMP-2 expression is low or absent in normal cervical epithelium, but generally high in cervical intraepithelial neoplasia and cervical cancer (16). Among cervical cancers, those with a higher expression of MMP-2 tend to have a poorer prognosis (16-19). MMP-2 expression can also be used as a marker for the differential diagnosis of benign cervical lesions and cervical cancer. Wang et al showed that MMP-2 expression is significantly upregulated in cervical cancer, compared with benign cervical lesions, and that MMP-2 expression is related to patient survival (17). Schröpfer et al analyzed the expression of MMPs in various gynecologic cancer cell lines and found that MMP-2 expression was moderate to strong in HeLa, CaSki and SiHa cervical cancer cell lines (18). Xie et al conducted a study involving 230 patients with cervical cancer and 230 healthy controls to investigate the relationship between the susceptibility and clinical outcomes of cervical cancer and genetic polymorphisms in the MMP-2, -3, -7 and -9 genes in a Chinese Han population. The results showed that certain genotypes of the MMP-2 and MMP-7 genes were associated with the progression of cervical cancer to the advanced stages and a poor survival in cervical cancer patients (19).

The results of the studies described above provide an important foundation for the exploration of a cervical cancer detection method based on targeting MMP-2. To date, the methods used to detect MMP-2 have mainly included western blotting, immunohistochemistry, zymography and enzymelinked immunosorbent assay. However, none of these methods can be used for the direct or real-time analysis of living cells or animals (20-25). Li et al prepared CdTe quantum dots as fluorophores for the detection of MMP-2 in tumors. However, the application of the probe was limited due to its high level of toxicity (26).

Non-invasive imaging technologies are important for understanding the operation and control of living systems, especially at the cellular level. Fluorescence imaging technologies have the advantages of detailed visualization, high sensitivity, and the potential for low toxicity. Such technologies can be used for the qualitative or quantitative detection of specific biomolecules in cells, tissues and whole animals in vivo, and can enable the precise localization of target analytes. Real-time monitoring of living processes is also possible using fluorescence imaging techniques (27).
In this study, a coumarin-based fluorescence resonance energy transfer (FRET) probe was prepared by coupling the fluorophore 7-[diethylamino]-2-oxo-2H-chromene3 -succinimidyl ester (Coumarin-Osu) with the quencher 4-(4-[dimethylamino]phenylazo)benzoic acid $N$-succinimidyl ester (Dabcyl-Osu) via a polypeptide chain (GPLGVRGKGG) that can be cleaved by MMP-2 (28-33). Through research using cervical cancer cell lines, it was demonstrated that this probe can detect MMP-2 in living cells and has promise for use in the screening, diagnosis and prognosis of cervical cancer.

\section{Materials and methods}

Reagents. 1-Ethyl-3-(3-dimethylaminopropyl)carbodiimide hydrochloride and $N$-hydroxysuccinimide were purchased from Sahn Chemical Technology (Shanghai, China). Dulbecco's modified Eagle's medium (DMEM) and fetal bovine serum (FBS) were purchased from Thermo Fisher Scientific (Waltham, MA, USA). TRIzol ${ }^{\circledR}$ reagent and a 100-bp DNA marker were purchased from Invitrogen (Carlsbad, CA, USA). Reverse transcription-polymerase chain reaction (RT-PCR) kit, Taq DNA polymerase and dNTPs were obtained from Takara Bio (Otsu, Japan). Primers were obtained from Invitrogen Trading (Shanghai, China). Goat anti-MMP-2 polyclonal antibody (sc-6838) was purchased from Santa Cruz Biotechnology, Inc. (Dallas, TX, USA). HRP-conjugated AffiniPure rabbit anti-goat IgG $(\mathrm{H}+\mathrm{L})(\mathrm{SA}-00001-4)$, mouse anti- $\beta$-actin monoclonal antibody (66009-1-Ig), and HRP-conjugated AffiniPure goat anti-mouse IgG (H+L) (SA-00001-1) were purchased from Proteintech (Rosemont, IL, USA). Polyvinylidene fluoride membrane, $N, N^{\prime}$-methylenebis(acrylamide), sodium dodecyl sulfate, ammonium sulfate, $N, N, N^{\prime} N^{\prime}-$ tetramethylethylenediamine, glycine, Whatman filter paper, non-fat milk powder, phenylmethanesulfonyl fluoride, trypsin, trishydroxymethyl-aminomethane (Tris), and Coomassie Brilliant Blue G-250 were purchased from Merck (Darmstadt, Germany). Recombinant MMP-2 protein was purchased from SinoBiological Inc. (Beijing, China). Human MMP-1 protein was purchased from PeproTech (Rocky Hill, NJ, USA). 4-Aminophenyl mercuric acetate (APMA) was obtained from InnoChem Technology (Beijing, China). All other chemicals were of analytic grade and used as received. Stock solutions $\left(2.0 \times 10^{-2} \mathrm{M}\right)$ of $\mathrm{Fe}^{3+}, \mathrm{K}^{+}, \mathrm{Na}^{+}, \mathrm{Mg}^{2+}, \mathrm{Ca}^{2+}, \mathrm{Cu}^{2+}, \mathrm{Fe}^{2+}$, $\mathrm{Zn}^{2+}, \mathrm{HCO}_{3}^{-}, \mathrm{NO}_{3}^{-}, \mathrm{ClO}_{4}^{-}, \mathrm{F}^{-}, \mathrm{Br}$, and amino acids such as L-tryptophan, L-serine, and L-aspartic acid were prepared in aqueous solutions. Stock solutions of 7-(diethylamino)-2-oxo$2 \mathrm{H}$-chromene-3-succinimidyl ester and MMP-2 probe $(20 \mu \mathrm{M})$ for spectral measurements were prepared in dimethyl sulfoxide (DMSO): $\mathrm{H}_{2} \mathrm{O}(1: 1,000, \mathrm{v} / \mathrm{v})$ solution. A stock solution of the MMP-2 probe for fluorescence imaging in cells was prepared in DMSO. TCNB buffer was comprised of $50 \mathrm{mM}$ Tris, $10 \mathrm{mM}$ $\mathrm{CaCl}_{2}, 150 \mathrm{mM} \mathrm{NaCl}$ and $0.05 \%$ (v/v) Brij 35 (with pH 7.5).

Instruments. ${ }^{1} \mathrm{H}$ nuclear magnetic resonance (NMR) and ${ }^{13} \mathrm{C}$ NMR spectra were measured using an Ascend ${ }^{\mathrm{TM}} 400$ spectrometer (Bruker, Billerica, MA, USA) and chemical shifts were reported as ppm, with tetramethylsilane as the internal standard. Mass spectrometric data were obtained using a Microtof-QIII ${ }^{\mathrm{TM}}$ mass spectrometer (Bruker). UV-vis absorption spectra were recorded using a UV2550 
spectrophotometer (Shimadzu, Kyoto, Japan). Fluorescence spectra were measured using a FS5 fluorescence spectrometer (Edinburgh Instruments, Livingston, UK). Other instruments used were as follows: FV10SW confocal laser scanning microscope (Olympus, Tokyo, Japan), JY92-II ultrasonic cell crusher (Ningbo Xinzhi Biological Polytron Technologies, Ningbo, China), $\mathrm{CO}_{2}$ incubator (model no. 5215-2; Shellab, Cornelius, OR, USA), StepOne ${ }^{\mathrm{TM}}$ real-time fluorescence quantitative PCR (qPCR) instrument (Applied Biosystems, Foster City, CA, USA), TE-70 semi-dry transfer film (GE Healthcare Life Sciences, Little Chalfont, UK), electrophoresis apparatus (model no. DYCP-31C; Liuyi Biotechnology, Beijing, China), and BioPhotometer ${ }^{\circledR}$ D30 nucleic acid protein analyzer (Eppendorf, Hamburg, Germany).

Cell lines. CaSki, SiHa, C33A and HeLa cervical cancer cell lines were obtained from the China Infrastruture of Cell Line Resources (catalog nos. 3142C0001000000829, 3142C0001000000089, 3142C0001000000132 and 3142C0001000000009, respectively). The cells were cultured in DMEM high glucose medium supplemented with $10 \%(\mathrm{v} / \mathrm{v})$ FBS, $100 \mathrm{U} / \mathrm{ml}$ penicillin, and $100 \mathrm{U} / \mathrm{ml}$ streptomycin. Cells were cultured at $37^{\circ} \mathrm{C}$ in a humidified incubator with $5 \% \mathrm{CO}_{2}$.

Activation and measurement of $M M P-2$. Initially, $75 \mu \mathrm{l}$ of MMP-2 (160 mM) and $75 \mu \mathrm{l}$ of APMA (5 mM) were mixed and reacted in an oscillator at $37^{\circ} \mathrm{C}$ for $2 \mathrm{~h}$ to activate MMP-2. Then, $150 \mu \mathrm{l}$ of activated MMP-2 $(80 \mathrm{mM})$ was added to $150 \mu \mathrm{l}$ of the MMP-2 probe $(20 \mu \mathrm{M})$ and mixed in the oscillator at $37^{\circ} \mathrm{C}$ for $180 \mathrm{~min}$. The test solutions were placed back into the oscillator at $37^{\circ} \mathrm{C}$ immediately after each measurement.

qPCR method. The total volume of each PCR reaction was $20 \mu \mathrm{l}$, which included $10 \mu \mathrm{l} 2 \mathrm{X} \mathrm{SYBR}^{\circledR}$ Premix Ex Taq ${ }^{\mathrm{TM}} \mathrm{II}$, $0.8 \mu \mathrm{l}$ forward primer $(10 \mu \mathrm{M}), 0.8 \mu \mathrm{l}$ reverse primer $(10 \mu \mathrm{M})$,

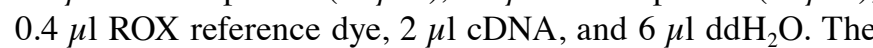
reaction conditions were as follows: $95^{\circ} \mathrm{C}$ for $30 \mathrm{sec}$, then 40 cycles of $95^{\circ} \mathrm{C}$ for $5 \mathrm{sec}$ and $60^{\circ} \mathrm{C}$ for $30 \mathrm{sec}$.

RT-PCR method. Total RNA was isolated from cells using TRIzol ${ }^{\circledR}$ purification. After denaturing RNA at $94^{\circ} \mathrm{C}$ for $5 \mathrm{~min}$, $500 \mathrm{ng}$ of RNA was transcribed into cDNA. Next, cDNA was amplified using the primers and target fragments. The amplification was performed using a thermocycler for 32 cycles according to the following program: $30 \mathrm{sec}$ at $94^{\circ} \mathrm{C}, 30 \mathrm{sec}$ at $58^{\circ} \mathrm{C}$, and $30 \mathrm{sec}$ at $72^{\circ} \mathrm{C}$. Final extension was performed at $72^{\circ} \mathrm{C}$ for $10 \mathrm{~min}$.

Western blot analysis. Firstly, $40 \mu \mathrm{g}$ of total proteins were separated by sodium dodecyl sulfate-polyacrylamide gel electrophoresis on a 10-12\% (v/v) gradient gel. Subsequently, proteins were transferred to polyvinylidene fluoride membranes and incubated with blocking buffer [phosphatebuffered saline (PBS) containing 5\% (w/v) non-fat skim milk] for $2 \mathrm{~h}$ at room temperature. Then, the membranes were incubated with primary antibodies (goat anti-MMP-2) with gentle shaking overnight at $4^{\circ} \mathrm{C}$, washed twice with PBS for $5 \mathrm{~min}$, and further incubated with secondary antibodies for $2 \mathrm{~h}$ at room temperature. Finally, MMP-2 was detected using a chemiluminescence reaction. Band staining intensity was measured using BandScan 5.0 software. Protein expression levels were normalized to $\beta$-actin protein.

Fluorescence imaging method. The MMP-2 fluorescence probe $(2 \mu \mathrm{M})$ was dissolved in PBS. CaSki, SiHa, C33A and HeLa cells were inoculated into confocal culture dishes. After $24 \mathrm{~h}$, the living cells, which were in the exponential phase of growth, were incubated with MMP-2 fluorescence probe for $120 \mathrm{~min}$ at $37^{\circ} \mathrm{C}$. Then, the cells were washed 3 times with PBS and observed using confocal laser scanning microscopy.

Statistical analysis. The collected data were analyzed using SPSS 19.0 software (IBM, Armonk, NY, USA) by one-way analysis of variance. Multiple comparisons among groups were performed using Fisher's least significant difference test. A P-value of $<0.05$ was considered to indicate a statistically significant result.

\section{Results and Discussion}

Preparation of the MMP-2 fluorescence probe. The procedures for the synthesis of the MMP-2 probe are shown in Fig. 1. Coumarin-Osu was used as a fluorescent chromophore and Dabcyl-Osu was used as a quencher for the preparation of the fluorescent MMP-2 probe. Coumarin-Osu was prepared conveniently according to previous literature (34-36). The UV-vis absorption spectrum of Coumarin-Osu $(10 \mu \mathrm{M})$ in DMSO: $\mathrm{H}_{2} \mathrm{O}(1: 1,000, \mathrm{v} / \mathrm{v})$ solution exhibited a broad coumarin-based $\pi-\pi^{*}$ transition band around $445 \mathrm{~nm}$. The fluorescence spectrum of the same solution showed a broad emission peak around $480 \mathrm{~nm}$ with strong green fluorescence. In contrast, Dabcyl-Osu, which shows maximum absorption at $480 \mathrm{~nm}$, is greatly effective in restraining the blue to green emission spectra of various fluorescent dyes and has often been used as a quencher in other studies. The emission spectrum of Coumarin-Osu and the absorption spectrum of Dabcyl-Osu overlapped enough to provide a basis for the synthesis of a probe. Thus, a coumarin-based fluorescence FRET probe was prepared by coupling the fluorophore (Coumarin-Osu) with the quencher (Dabcyl-Osu) through a polypeptide chain (GPLGVRGKGG) that can be cleaved by MMP-2. The constructed probe was characterized by matrix-assisted laser desorption/ionization-time of flight mass spectrometry (MALDI-TOF) and high-pressure liquid chromatography (HPLC). MALDI-TOF: calculated for $[\mathrm{M}+\mathrm{H}]^{+}:$1391.72, found: 1392.09 . Purity (HPLC): $98.0533 \%$. In the normal biological environment, FRET between the fluorophore and the quencher caused effective fluorescence quenching. However, upon cleavage of the polypeptide chain (GPLGVRGKGG) between G and V of the core MMP-2 substrate sequence PLGVR, the fluorophore and quencher were separated (Fig. 2) (37,38). Thus, the fluorescence of coumarin was recovered.

Fluorescence responses of the probe to MMP-2, MMP-1 and biologically relevant chemical species. To explore the practicality of the designed probe for the measurement of MMP-2 in living systems, the dynamic fluorescence spectra of the probe $(10 \mu \mathrm{M}$, DMSO:TCNB buffer $=1: 1,000, \mathrm{v} / \mathrm{v})$ which was incubated with MMP-2 were measured over time. As shown 
<smiles>CCN(CC)c1ccc(N(CC)CC)c(O)c1</smiles>

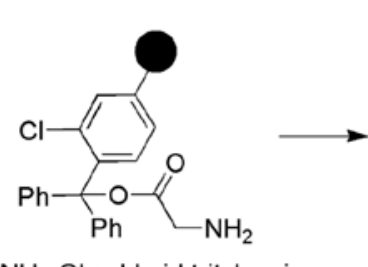

$\mathrm{NH}_{2}$-Gly-chlorid trityl resin

4

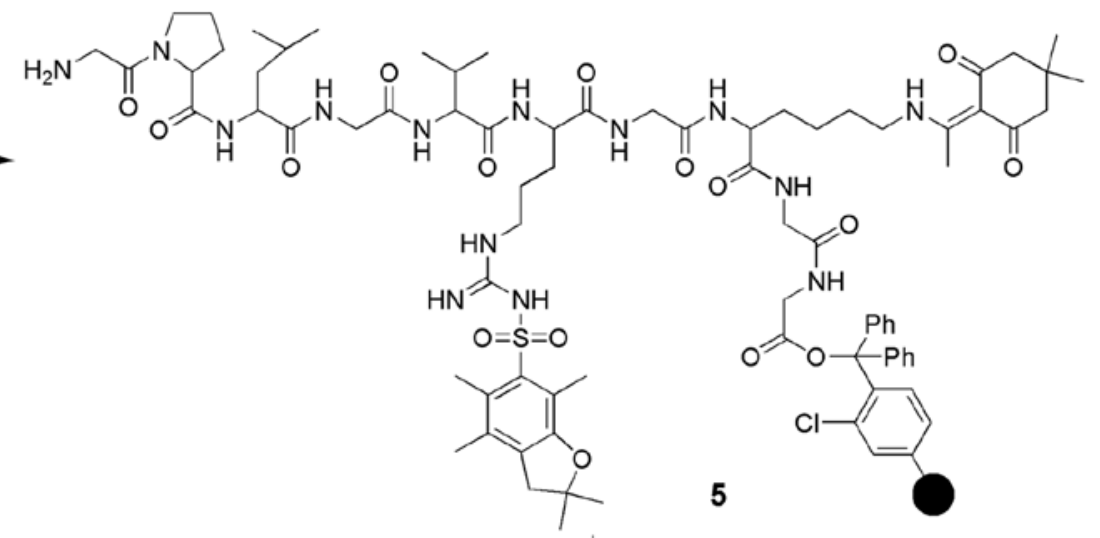

3, DIEA, $4 \mathrm{~h}$<smiles>CCN(CC)c1ccc2cc(C(N)=O)c(=O)oc2c1</smiles><smiles>CCN(CC)c1ccc2cc(C(N)=O)c(=O)oc2c1</smiles>

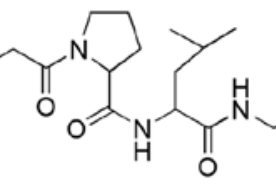

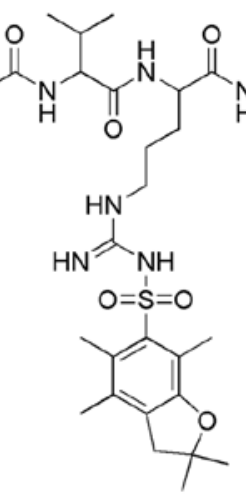
6<smiles>CC(NCCCCC(C)N)=C1C(=O)CC(C)(C)CC1=O</smiles><smiles>CCCC(=O)NCC(=O)OC(c1ccccc1)(c1ccccc1)c1ccc(C)cc1Cl</smiles>

$1,5 \%$ hydrazine in DMF 2, Dabcyl-Osu, DIEA, 4 h<smiles>CCCC(NC(=O)C(NC(C)=O)C(C)C)C(=O)NCC(=O)NC(CCCCNC(=O)c1ccc(N=Nc2ccc(NC)cc2)cc1)C(=O)NC</smiles><smiles>CCCNC(=N)NS(=O)(=O)c1c(C)c(C)c2c(c1C)OC(C)(C)C2</smiles>

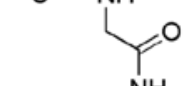<smiles>COc1ccc(C(OC(=O)CN)(c2ccccc2)c2ccccc2)c(Cl)c1</smiles>

TFA/TIS/ $\mathrm{H}_{2} \mathrm{O}(95: 5: 5), 2.5 \mathrm{~h}$<smiles>CCN(CC)c1ccc2cc(C(=O)NCC(=O)N3CCCC3C(=O)NC(CC(C)C)C(=O)NCC(=O)NC(C(=O)NC(CCCNC(=N)N)C(=O)NCC(=O)NC(CCCCNC(=O)c3ccc(N=Nc4ccc(N(C)C)cc4)cc3)C(=O)NCC(=O)NCC(=O)O)C(C)C)c(=O)oc2c1</smiles>

Figure 1. Procedures used for the synthesis of the matrix metalloproteinase-2 (MMP-2) probe. 


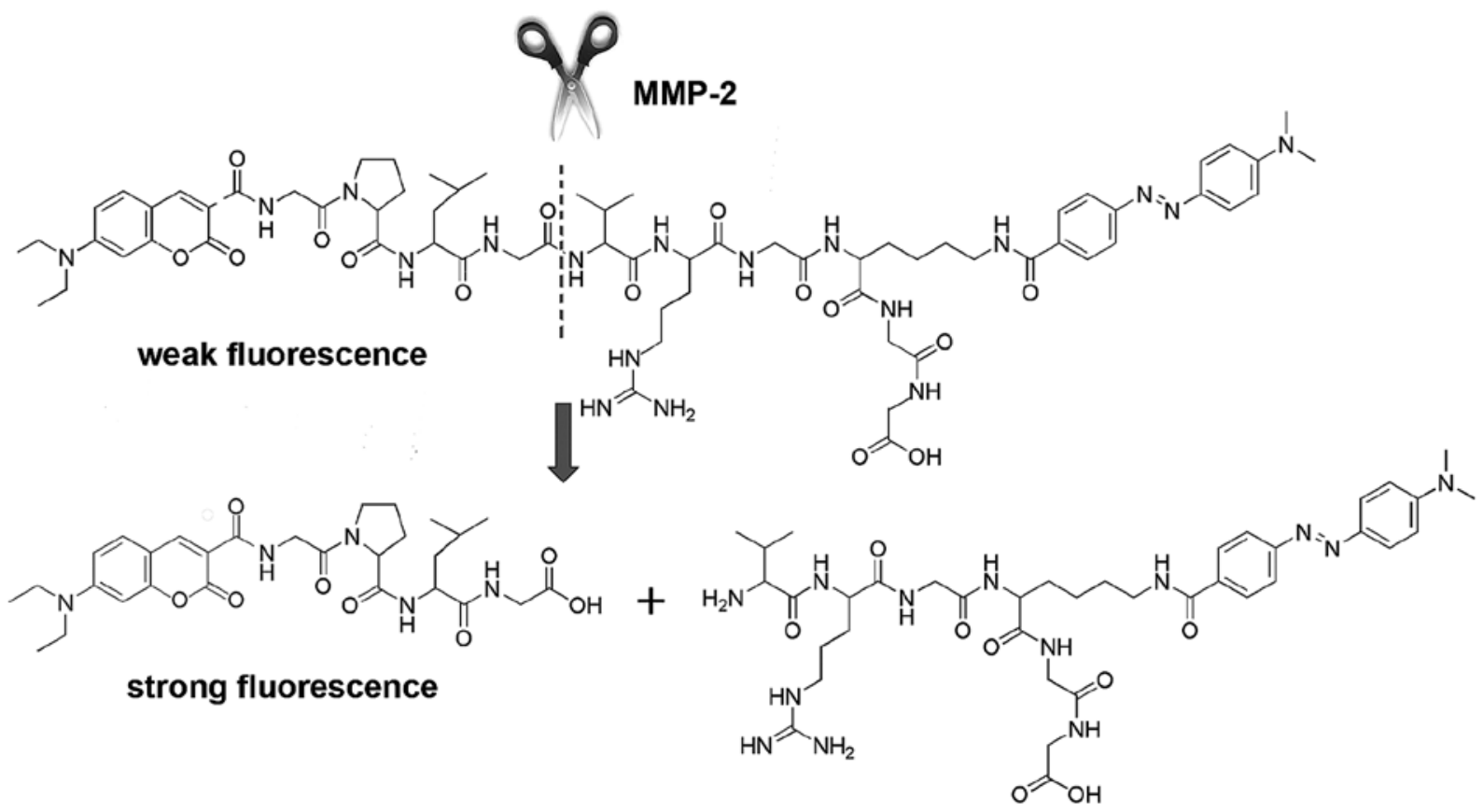

Figure 2. Process for detection of the probe target matrix metalloproteinase-2 (MMP-2).

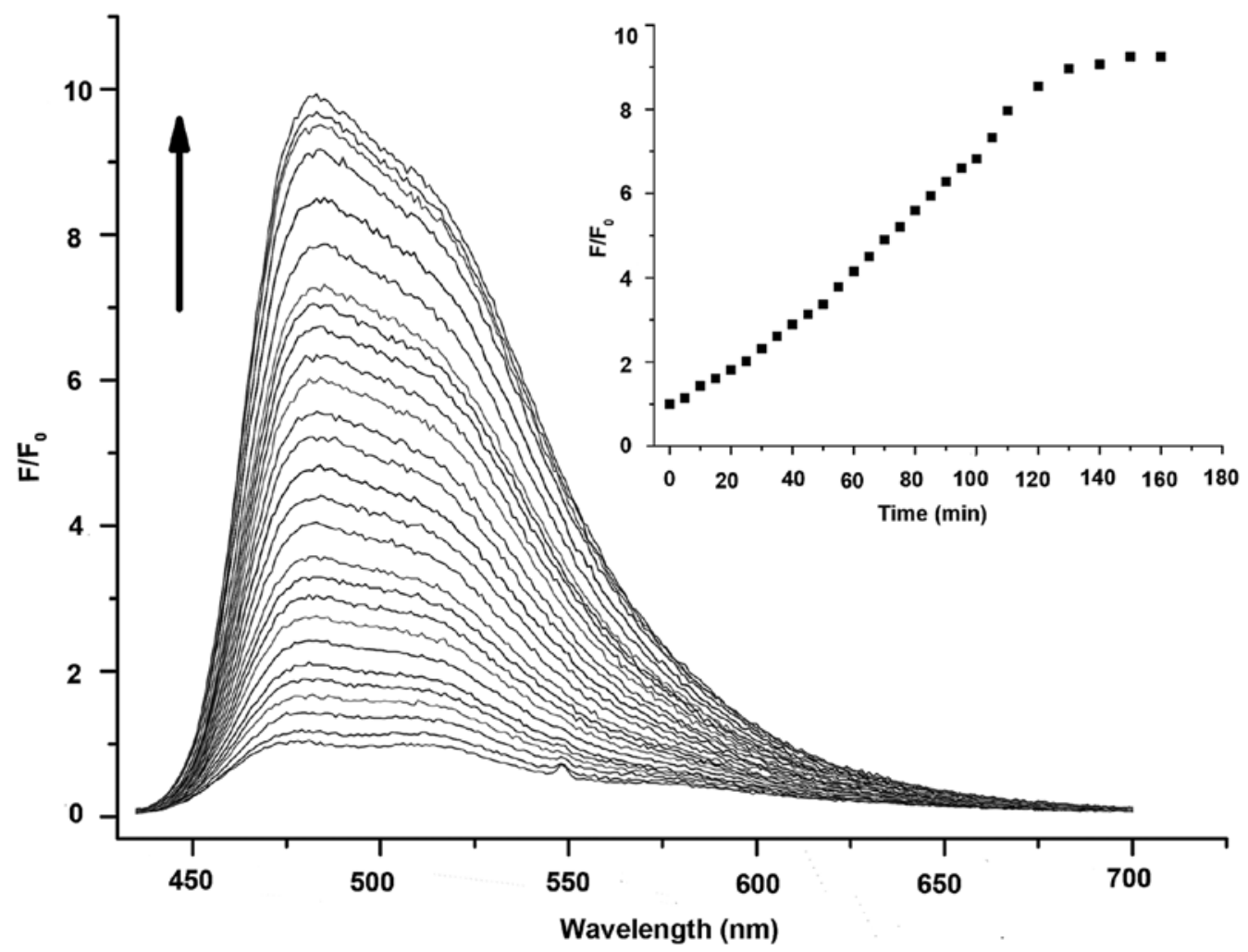

Figure 3. Changes in the fluorescence emission spectra of the matrix metalloproteinase-2 (MMP-2) probe (10 $\mu \mathrm{M})$ in TCNB buffer solution over time. Insert: fluorescence intensity was recorded at $480 \mathrm{~nm}$ with excitation at $425 \mathrm{~nm}$.

in Fig. 3, the fluorescence intensity of the probe itself was very weak in the beginning. However, it increased obviously with emission at $480 \mathrm{~nm}$ as time went on and then leveled off after $\sim 2 \mathrm{~h}$. The fluorescence intensity of the probe increased by $\sim 10$-fold (39). Selective experiments of the probe for the target molecule were carried out at lower concentrations for practical application. When other biologically relevant species such as MMP-1 (10 nM), $\mathrm{K}^{+}, \mathrm{Mg}^{2+}, \mathrm{Na}^{+}, \mathrm{Fe}^{3+}, \mathrm{Cu}^{2+}, \mathrm{Zn}^{2+}, \mathrm{Ca}^{2+}$, L-tryptophan, L-serine, L-aspartic acid, $\mathrm{HCO}_{3}^{-}, \mathrm{NO}_{3}{ }^{-}, \mathrm{ClO}_{4}^{-}$, $\mathrm{F}^{-}$and $\mathrm{Br}^{-}$(all $10 \mathrm{mM}$ ) were incubated with the probe $(20 \mathrm{nM})$ at $37^{\circ} \mathrm{C}$ for $2 \mathrm{~h}$, no obvious changes in the fluorescence spectra were observed (Fig. 4). For practical application, it was 


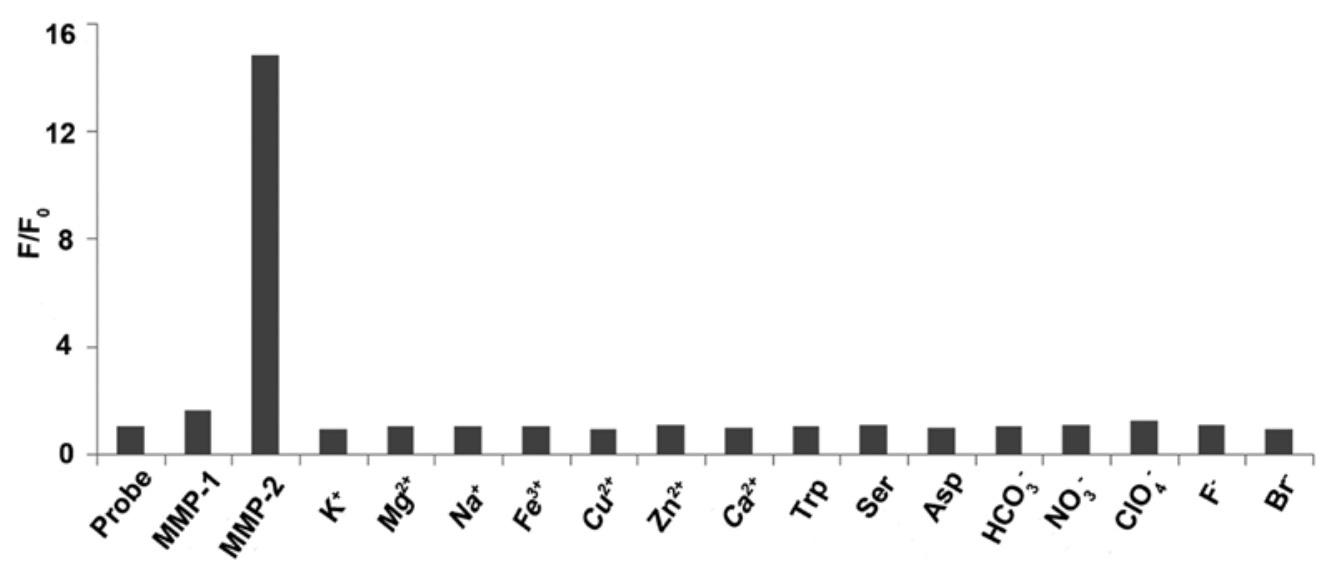

Figure 4. Fluorescence responses of the matrix metalloproteinase-2 (MMP-2) probe (20 nM) to MMP-1, MMP-2, and various other species. MMP-1 (10 nM), MMP-2 $(10 \mathrm{nM})$, and other species (all $10 \mathrm{mM}$ ) were individually reacted with the MMP-2 probe at $37^{\circ} \mathrm{C}$ for $2 \mathrm{~h}$.

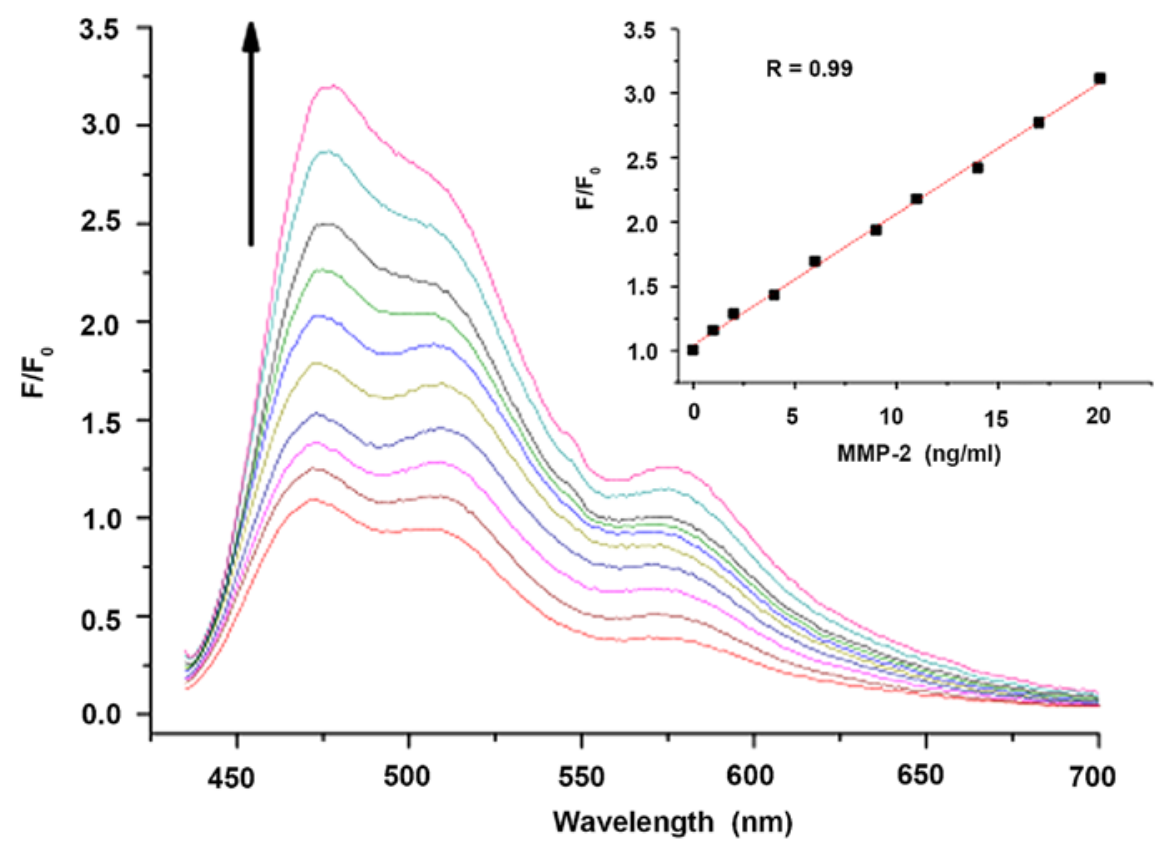

Figure 5. The fluorescence intensity of the probe $(10 \mu \mathrm{M})$ was correlated with matrix metalloproteinase-2 (MMP-2) concentrations $(0.0,0.5,1.0,2.0,3.0,4.5$, $5.5,7.0,8.5$ and $10 \mathrm{ng} / \mathrm{ml}$ ). Inset: the linear regression of the fluorescence intensity at $480 \mathrm{~nm}$ vs. the concentration of MMP-2.

necessary to investigate the limit of detection (LOD) and the detection range of the probe targeting MMP-2 by means of calibrating the fluorescence assay $(40,41)$. The fluorescence titration of the probe $(10 \mu \mathrm{M})$ upon the addition of activated MMP-2 (0.0, 0.5, 1.0, 2.0, 3.0, 4.5, 5.5, 7.0, 8.5 and $10 \mathrm{ng} / \mathrm{ml})$ in TCNB buffer solution was performed (Fig. 5). Each test was conducted after the probe was incubated with MMP-2 for $2 \mathrm{~h}$. The linear regression of the fluorescence intensity $\left(\mathrm{F} / \mathrm{F}_{0}\right.$, at $480 \mathrm{~nm}$ ) vs. the concentration of MMP-2 is shown in Fig. 5 inset. The probe featured an LOD for MMP-2 up to $0.05 \mathrm{ng} / \mathrm{ml}$ with the emission intensity increasing $23 \%$. Moreover, the fluorescence intensity was linearly correlated with the concentration of MMP-2 in the range of $0.05-10 \mathrm{ng} / \mathrm{ml}$. The lower limit of LOD hinted a higher sensitivity to detect MMP-2, indicating the possibility of potent application for the early diagnosis of cervical carcinoma through collection of exfoliated cells from the vagina, and following regular cell culture technique to obtain massive cervical carcinoma cells. The cells can be used for MMP-2 fluorescence analysis via a fluorescent reader. Definitely a reliable control is required based on pathological criteria, which will be the focus of subsequent research by us.

Detection of MMP-2 expression using qPCR. qPCR was used to detect the expression of MMP-2 mRNA in the 4 cervical cancer cell lines for preliminary screening. Total RNA was isolated from cells using TRIzol ${ }^{\circledR}$ purification and first-strand cDNA was synthesized using a qPCR kit. Specific primers were as follows: MMP-2 sense, 5'-TGGGGCCTCTCCTGAC ATTGA-3' and antisense, 5'-CACAGTCCGCCAAATGAA CCG-3'; glyceraldehyde 3-phosphate dehydrogenase (GAPDH) sense, 5'-AGAAGGCTGGGGCTCATTTG-3' and antisense, 5'-AGGGGCCATCCACAGTCTTC-3'. The target fragments were 157 and $258 \mathrm{bp}$, respectively. The expression of MMP-2 was detected by fluorescence qPCR using cDNA as a template. 
Table I. MMP-2 mRNA expression levels in 4 cervical cell lines, as determined by qPCR.

\begin{tabular}{lccc}
\hline Cell lines & $2^{-\Delta \Delta \mathrm{Ct}}($ mean $\pm \mathrm{SD})$ & F-value & P-value \\
\hline CaSki & $11.028 \pm 0.074^{\mathrm{a}}$ & 3467.610 & 0.000 \\
SiHa & $9.700 \pm 0.023^{\mathrm{a}}$ & & \\
C33-A & $3.151 \pm 0.148^{\mathrm{a}}$ & & \\
HeLa & $0.000 \pm 0.260^{\mathrm{a}}$ & & \\
\hline
\end{tabular}

${ }^{\text {ap }}<0.01$ comparison between the 2 groups. MMP-2, matrix metalloproteinase-2.

Table II. Expression of MMP-2 mRNA in 4 cervical cancer cell lines, as determined by RT-PCR.

\begin{tabular}{lc}
\hline Cell lines & Grayscale ratio (mean \pm SD) \\
\hline CaSki & $0.880 \pm 0.016^{\mathrm{a}}$ \\
SiHa & $0.695 \pm 0.018^{\mathrm{a}}$ \\
C33-A & $0.221 \pm 0.010^{\mathrm{a}}$ \\
HeLa & $0.0951 \pm 0.008^{\mathrm{a}}$ \\
F-value & 2245.500 \\
P-value & 0.000 \\
\hline
\end{tabular}

${ }^{\mathrm{a}} \mathrm{P}<0.01$ comparison between the 2 groups. MMP-2, matrix metalloproteinase-2.

Table III. Expression of MMP-2 protein in 4 cervical cancer cell lines, as determined by western blotting.

\begin{tabular}{lccc}
\hline Cell lines & $\begin{array}{c}\text { Grayscale ratio } \\
(\text { MMP2/ } \beta \text {-actin })\end{array}$ & F-value & P-value \\
\hline CaSki & $1.044 \pm 0.069^{\mathrm{a}}$ & 163.726 & 0.000 \\
SiHa & $0.870 \pm 0.038^{\mathrm{b}}$ & & \\
C33-A & $0.766 \pm 0.014$ & & \\
HeLa & $0.316 \pm 0.023^{\mathrm{c}}$ & & \\
\hline
\end{tabular}

${ }^{\mathrm{a}} \mathrm{P}<0.01$ vs. SiHa cells, C33A cells, HeLa cells; ${ }^{\mathrm{b}} \mathrm{P}<0.05$ vs. C33A cells; ${ }^{\mathrm{c}} \mathrm{P}<0.01$ vs. SiHa cells, C33A cells. MMP-2, matrix metalloproteinase-2.

The amplification plot and melting curve showed a single amplification product without non-specific amplification and without miscellaneous melting curve peaks. The results indicated that MMP-2 expression in cervical cancer cell lines was ordered as $\mathrm{CaSki}>\mathrm{SiHa}>\mathrm{C} 33 \mathrm{~A}>\mathrm{HeLa}$ (Fig. 6). Each reaction was performed in triplicate and analyzed individually. The results were calculated using the $2^{-\Delta \Delta \mathrm{Ct}}$ relative quantification method and normalized using HeLa cells as a reference control and glyceraldehyde-3-phosphate dehydrogenase (GAPDH) as an internal standard (Table I).

Detection of MMP-2 expression using RT-PCR. RT-PCR was used to examine the expression of MMP-2 mRNA in the

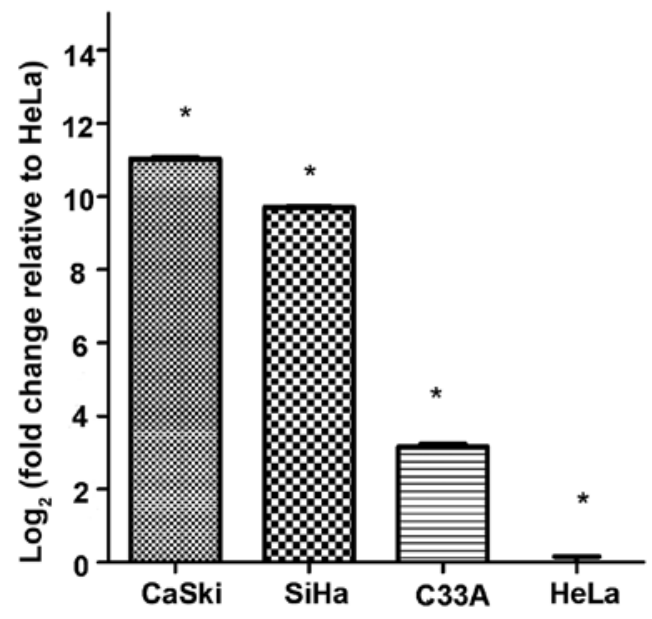

Figure 6. The expression levels of matrix metalloproteinase-2 (MMP-2) in the 4 cervical cell lines were ordered as: $\mathrm{CaSki}>\mathrm{SiHa}>\mathrm{C} 33 \mathrm{~A}>\mathrm{HeLa}$, and analysis of variance showed that the differences among groups were statistically significant.

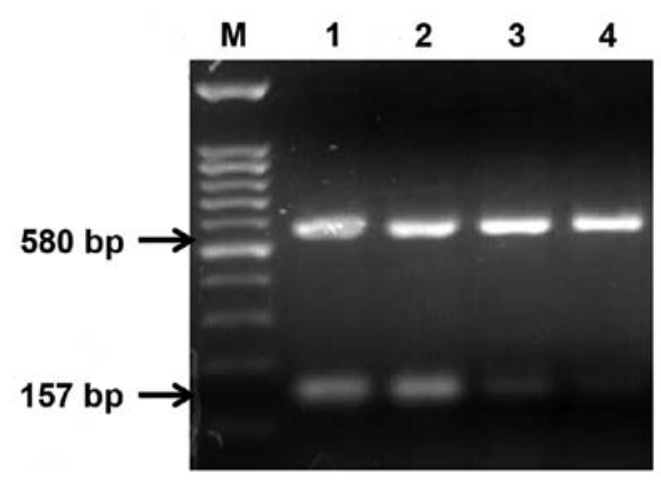

Figure 7. Results of RT-PCR analysis showed that matrix metalloproteinase-2 (MMP-2) expression levels in the 4 cervical cancer cell lines were ordered as: $\mathrm{CaSki}>\mathrm{SiHa}>\mathrm{C} 33 \mathrm{~A}>\mathrm{HeLa}$. Lane 1, SiHa cells; lane 2, CaSki cells; lane 3, C33A cells; lane 4, HeLa cells; lane M, 100-bp DNA ladder.

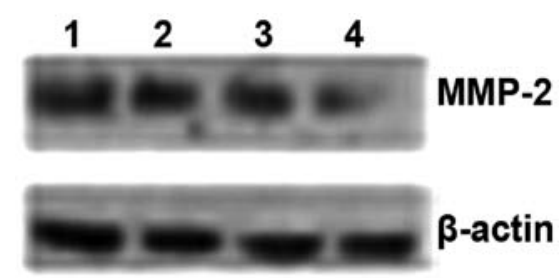

Figure 8. Western blot analysis indicated that the expression levels of matrix metalloproteinase-2 (MMP-2) in the 4 cervical cancer cell lines were ordered as follows: CaSki cells $>\mathrm{SiHa}$ cells $>\mathrm{C} 33 \mathrm{~A}$ cells $>$ HeLa cells. Lane 1, CaSki cells; lane 2, SiHa cells; lane 3, C33A cells; lane 4, HeLa cells.

4 cervical cancer cell lines. Specific primers were as follows: MMP-2 sense, 5'-TGGGGCCTCTCCTGACATTGA-3' and antisense, 5'-CACAGTCCGCCAAATGAACCG-3', 157 bp; GAPDH sense, 5'-AATCCCATCACCATCTTCCA-3' and antisense, 5'-CCTGCTTCACCACCTTCTTG-3', 580 bp. PCR fragments were separated by electrophoresis on a $1.5 \%(\mathrm{w} / \mathrm{v})$ agarose gel with GAPDH as an internal control. The results indicated that the relative MMP-2 gene expression levels in the 4 cervical cancer cell lines were ordered as follows: 

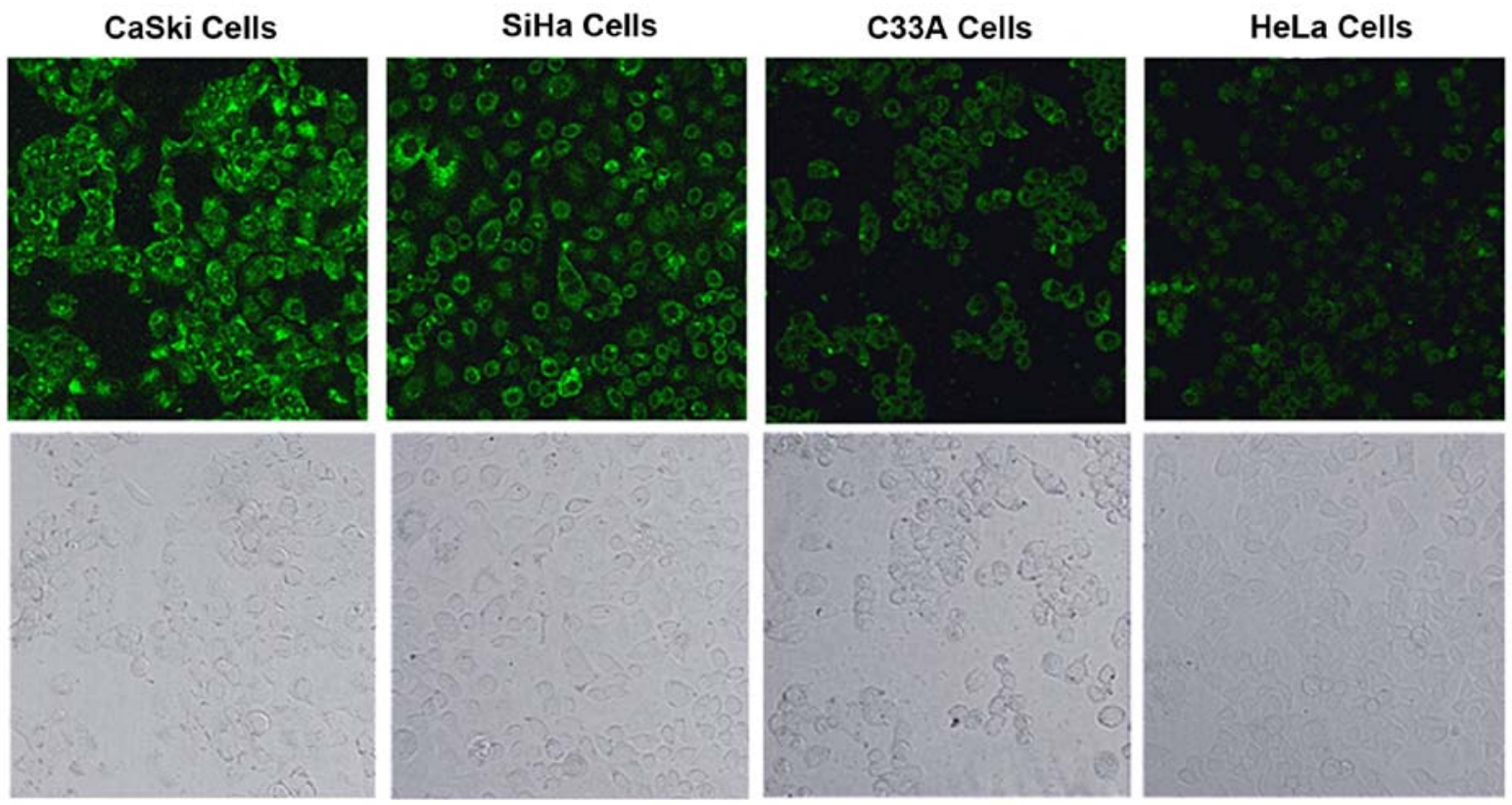

Figure 9. Fluorescence images of the matrix metalloproteinase-2 (MMP-2) probe after its application in 4 cervical cancer cell lines: from left to right are CaSki cells, SiHa cells, C33A cells, HeLa cells and their corresponding bright field images.

CaSki $>$ SiHa $>$ C33A > HeLa (Fig. 7). The PCR products were analyzed and data calculations were performed using GeneTools gel analysis software (Syngene, Cambridge, UK), and GAPDH was used as an internal control for data normalization (Table II).

Detection of MMP-2 expression by western blotting. Western blotting was used to investigate the expression of MMP-2 protein in the 4 cervical cancer cell lines. Western blot results revealed that the expression of MMP-2 protein in the 4 cervical cancer cell lines was ordered as follows: $\mathrm{CaSki}>\mathrm{SiHa}>\mathrm{C} 33 \mathrm{~A}$ $>$ HeLa (Fig. 8 and Table III).

Fluorescence imaging. The mRNA and protein expression of the MMP-2 gene in 4 cervical cancer cell lines was examined by qPCR, RT-PCR and western blotting. The results illustrated that the expression of the MMP-2 gene differed among the 4 tested cell lines, which provided a basis for the cell imaging experiments. After the 4 cervical cancer cell lines were incubated individually with the fluorescence probe for $120 \mathrm{~min}$ at $37^{\circ} \mathrm{C}$, fluorescence images were acquired using confocal laser scanning microscopy. The fluorescence intensities were in the following order: $\mathrm{CaSki}>\mathrm{SiHa}>\mathrm{C} 33 \mathrm{~A}>\mathrm{HeLa}$, which were consistent with the experimental results of qPCR, RT-PCR and western blotting (Fig. 9).

In conclusion, a coumarin-based FRET probe targeting MMP-2 was successfully designed, synthesized and used to measure MMP-2 expression in 4 cervical cancer cell lines. The cell lines showed green fluorescence with intensities in the order of CaSki $>\mathrm{SiHa}>\mathrm{C} 33 \mathrm{~A}>\mathrm{HeLa}$. These results were consistent with those of qPCR, RT-PCR and western blotting. Taken together, the findings indicate that the fluorescence probe accurately measures MMP-2 expression in living cervical cancer cells. In vivo fluorescence imaging experiments and clinical trials are underway.

\section{Acknowledgements}

The present study was financially supported by the National Natural Science Foundation (nos. 21371148 and 21571153), the Key Scientific and Technological Project of Henan Province (no. 122102310196), and the Education Project of Henan Province (no. 12A150019).

\section{References}

1. Torre LA, Siegel RL, Ward EM and Jemal A: Global cancer incidence and mortality rates and trends-an update. Cancer Epidemiol Biomarkers Prev 25: 16-27, 2016.

2. Wang T, Wu MH, Wu YM and Zhang WY: A population-based study of invasive cervical cancer patients in Beijing: 1993-2008. Chin Med J (Engl) 128: 3298-3304, 2015.

3. Sankaranarayanan R, Qiao YL and Keita N: The next steps in cervical screening. Wom Health Lond 11: 201-212, 2015.

4. Catarino R, Petignat P, Dongui G and Vassilakos P: Cervical cancer screening in developing countries at a crossroad: Emerging technologies and policy choices. World J Clin Oncol 6: 281-290, 2015.

5. Yi DK, Sun IC, Ryu JH, Koo H, Park CW, Youn IC, Choi K, Kwon IC, Kim K and Ahn CH: Matrix metalloproteinase sensitive gold nanorod for simultaneous bioimaging and photothermal therapy of cancer. Bioconjug Chem 21: 2173-2177, 2010.

6. Wang Y, Shen P, Li C, Wang Y and Liu Z: Upconversion fluorescence resonance energy transfer based biosensor for ultrasensitive detection of matrix metalloproteinase-2 in blood. Anal Chem 84: 1466-1473, 2012.

7. Wang H, Udukala DN, Samarakoon TN, Basel MT, Kalita M, Abayaweera G, Manawadu H, Malalasekera A, Robinson C, Villanueva D, et al: Nanoplatforms for highly sensitive fluorescence detection of cancer-related proteases. Photochem Photobiol Sci 13: 231-240, 2014.

8. Zhu L, Xie J, Swierczewska M, Zhang F, Quan Q, Ma Y, Fang X, Kim K, Lee S and Chen X: Real-time video imaging of protease expression in vivo. Theranostics 1: 18-27, 2011.

9. Madsen DH and Bugge TH: The source of matrix-degrading enzymes in human cancer: Problems of research reproducibility and possible solutions. J Cell Biol 209: 195-198, 2015.

10. Theocharis AD, Skandalis SS, Gialeli C and Karamanos NK: Extracellular matrix structure. Adv Drug Deliv Rev 97: 4-27, 2016.

11. Lombard C, Saulnier J and Wallach J: Assays of matrix metalloproteinases (MMPs) activities: A review. Biochimie 87: 265-272, 2005. 
12. Tveitarås MK, Skogstrand T, Leh S, Helle F, Iversen BM, Chatziantoniou C, Reed RK and Hultström M: Matrix metalloproteinase- 2 knockout and heterozygote mice are protected from hydronephrosis and kidney fibrosis after unilateral ureteral obstruction. PLoS One 10: e0143390, 2015.

13. Xu C, Wang C, Cai QF, Zhang Q, Weng L, Liu GM, Su WJ and Cao MJ: Matrix metalloproteinase 2 (MMP-2) plays a critical role in the softening of common carp muscle during chilled storage by degradation of type I and V collagens. J Agric Food Chem 63: 10948-10956, 2015.

14. Yi GZ, Feng WY, Zhou Q, Liu YW and Qi ST: The impact of MMP-2 and its specific inhibitor TIMP-2 expression on the WHO grade and prognosis of gliomas in Chinese population: A Meta-Analysis. Mol Neurobiol 54: 22-30: 2017.

15. Hanahan D and Weinberg RA: Hallmarks of cancer: The next generation. Cell 144: 646-674, 2011

16. Ghosh A, Moirangthem A, Dalui R, Ghosh T, Bandyopadhyay A, Dasgupta A, Banerjee U, Jana N and Basu A: Expression of matrix metalloproteinase-2 and 9 in cervical intraepithelial neoplasia and cervical carcinoma among different age groups of premenopausal and postmenopausal women. J Cancer Res Clin Oncol 140: 1585-1593, 2014.

17. Wang L, Wang Q, Li HL and Han LY: Expression of MiR200a, miR93, metastasis-related gene RECK and MMP2/MMP9 in human cervical carcinoma - relationship with prognosis. Asian Pac J Cancer Prev 14: 2113-2118, 2013.

18. Schröpfer A, Kammerer U, Kapp M, Dietl J, Feix S and Anacker J: Expression pattern of matrix metalloproteinases in human gynecological cancer cell lines. BMC Cancer 10: 553, 2010.

19. Xie B, Zhang Z, Wang H, Chen Z, Wang Y, Liang H, Yang G, Yang $\mathrm{X}$ and Zhang $\mathrm{H}$ : Genetic polymorphisms in MMP2, 3, 7 , and 9 genes and the susceptibility and clinical outcome of cervical cancer in a Chinese Han population. Tumour Biol 37: 4883-4888, 2016.

20. Dutra KL, Cordeiro MM, Vieira DS and Rivero ER: Immunohistochemical expression of matrix metalloproteinases in ameloblastomas and pericoronal follicles. J Oral Pathol Med 45: 586-590, 2016.

21. Gunawardena I, Arendse M, Jameson MB, Plank LD and Gregor RT: Prognostic molecular markers in head and neck squamous cell carcinoma in a New Zealand population: Matrix metalloproteinase-2 and sialyl Lewis $\mathrm{x}$ antigen. ANZ J Surg 85: 843-848, 2015

22. Lee S, Ryu JH, Park K, Lee A, Lee SY, Youn IC, Ahn CH, Yoon SM, Myung SJ, Moon DH, et al: Polymeric nanoparticlebased activatable near-infrared nanosensor for protease determination in vivo. Nano Lett 9: 4412-4416, 2009.

23. Liang GX, Pan HC, Li Y, Jiang LP, Zhang JR and Zhu JJ: Near infrared sensing based on fluorescence resonance energy transfer between Mn:CdTe quantum dots and Au nanorods. Biosens Bioelectron 24: 3693-3697, 2009.

24. Bremer C, Bredow S, Mahmood U, Weissleder R and Tung CH: Optical imaging of matrix metalloproteinase-2 activity in tumors: Feasibility study in a mouse model. Radiology 221: 523-529, 2001

25. Zajac A, Song D, Qian W and Zhukov T: Protein microarrays and quantum dot probes for early cancer detection. Colloids Surf B Biointerfaces 58: 309-314, 2007.
26. Li X, Deng D, Xue J, Qu L, Achilefu S and Gu Y: Quantum dots based molecular beacons for in vitro and in vivo detection of MMP-2 on tumor. Biosens Bioelectron 61: 512-518, 2014.

27. Schäferling M: The art of fluorescence imaging with chemical sensors. Angew Chem Int Ed Engl 51: 3532-3554, 2012.

28. Knight CG, Willenbrock F and Murphy G: A novel coumarinlabelled peptide for sensitive continuous assays of the matrix metalloproteinases. FEBS Lett 296: 263-266, 1992.

29. Aggarwal M, Sharma R, Kumar P, Parida M and Tomar S: Kinetic characterization of trans-proteolytic activity of Chikungunya virus capsid protease and development of a FRET-based HTS assay. Sci Rep 5: 14753, 2015.

30. Zhang M, Yin BC, Wang XF and Ye BC: Interaction of peptides with graphene oxide and its application for real-time monitoring of protease activity. Chem Commun (Camb) 47: 2399-2401, 2011

31. Myochin T, Hanaoka K, Komatsu T, Terai T and Nagano T: Design strategy for a near-infrared fluorescence probe for matrix metalloproteinase utilizing highly cell permeable boron dipyrromethene. J Am Chem Soc 134: 13730-13737, 2012.

32. Kim J, Cote LJ, Kim F and Huang J: Visualizing graphene based sheets by fluorescence quenching microscopy. J Am Chem Soc 132: 260-267, 2010.

33. Feng D, Zhang Y, Feng T, Shi W, Li X and Ma H: A graphene oxide-peptide fluorescence sensor tailor-made for simple and sensitive detection of matrix metalloproteinase 2. Chem Commun (Camb) 47: 10680-10682, 2011.

34. Ma Y, Luo W, Quinn PJ, Liu Z and Hider RC: Design, synthesis, physicochemical properties, and evaluation of novel iron chelators with fluorescent sensors. J Med Chem 47: 6349-6362, 2004.

35. He G, Guo D, He C, Zhang X, Zhao X and Duan C: A colortunable europium complex emitting three primary colors and white light. Angew Chem Int Ed Engl 48: 6132-6135, 2009.

36. Albers AE, Okreglak VS and Chang CJ: A FRET-based approach to ratiometric fluorescence detection of hydrogen peroxide. J Am Chem Soc 128: 9640-9641, 2006.

37. Zhu L, Zhang F, Ma Y, Liu G, Kim K, Fang X, Lee S and Chen X: In vivo optical imaging of membrane-type matrix metalloproteinase (MT-MMP) activity. Mol Pharm 8: 2331-2338, 2011.

38. Fields GB: Using fluorogenic peptide substrates to assay matrix metalloproteinases. Methods Mol Biol 622: 393-433, 2010.

39. Netzel-Arnett S, Mallya SK, Nagase H, Birkedal-Hansen H and Van Wart HE: Continuously recording fluorescent assays optimized for five human matrix metalloproteinases. Anal Biochem 195: 86-92, 1991.

40. Song E, Cheng D, Song Y, Jiang M, Yu J and Wang Y: A graphene oxide-based FRET sensor for rapid and sensitive detection of matrix metalloproteinase 2 in human serum sample. Biosens Bioelectron 47: 445-450, 2013.

41. Udukala DN, Wang H, Wendel SO, Malalasekera AP, Samarakoon TN, Yapa AS, Abayaweera G, Basel MT, Maynez P, Ortega R, et al: Early breast cancer screening using iron/iron oxide-based nanoplatforms with sub-femtomolar limits of detection. Beilstein J Nanotechnol 7: 364-373, 2016. 